\title{
Prediction of boron adsorption on some soils of State Paraná, Brazil
}

\section{Adsorção de boro em alguns solos do Estado do Paraná}

\author{
Maria do Carmo Lana ${ }^{1}$; Fábio Steiner ${ }^{2}$; Tiago $\mathrm{Zoz}^{2}$; \\ Jucenei Fernando Frandoloso ${ }^{3}$; Rubens Fey ${ }^{4}$
}

\begin{abstract}
Boron adsorption in soils affects their behavior in the environment and their availability to plants. This study investigated the effect of liming on B adsorption in different soils from Paraná State, and to correlate these values with some physical and chemical properties of the soils. Surface samples $(0-0.2$ $\mathrm{m}$ ) of nine soils with different parent material and physicochemical properties were used. Samples with or without lime application were incubated for 60 days. Boron adsorption was accomplished by shaking $4.0 \mathrm{~g}$ soil, for $24 \mathrm{~h}$, with $20 \mathrm{~mL}$ of $0.01 \mathrm{~mol} \mathrm{~L}^{-1} \mathrm{CaCl}_{2}$ solution containing different concentrations of $\mathrm{B}$ $\left(0,1,2,4,8\right.$ and $\left.16 \mathrm{mg} \mathrm{L}^{-1}\right)$. Sorption was fitted to non-linear form of the Langmuir adsorption isotherm. Boron adsorption increased as concentration increased. Maximum adsorption capacity (MAC) of B ranged from 2.3 to $42.9 \mathrm{mg} \mathrm{kg}^{-1}$ (without lime) and 22.7 to $109.9 \mathrm{mg} \mathrm{kg}^{-1}$ (with lime). The two Arenic Hapludalf have had the highest B adsorption capacity, whereas the sandy-textured Arenic Hapludult (Ult1) had the lowest values. Liming increased the amount of adsorbed B on the soils, except in the Typic Hapludox (Ox4) and Arenic Hapludult (Ult2). The bonding energy (K) decreased with the lime in most soils, indicating that at higher $\mathrm{pH}$ values the $\mathrm{B}$ is adsorbed more weakly. The soil $\mathrm{pH}$, the organic matter, and the contents of silicon oxide $\left(\mathrm{SiO}_{2}\right)$ and aluminum oxide $\left(\mathrm{Al}_{2} \mathrm{O}_{3}\right)$ were the soils properties that affecting the B adsorption on Paraná soils.
\end{abstract}

Key words: Langmuir isotherm, maximum adsorption capacity, liming, boron fertilizer

\section{Resumo}

A adsorção de $\mathrm{B}$ pelo solo afeta o seu comportamento no meio ambiente e sua disponibilidade para às plantas. Este estudo teve como objetivo avaliar o efeito da calagem na adsorção de B em solos do Estado do Paraná, e correlacionar estes valores com os atributos químicos e físicos do solo. Foram utilizadas amostras da camada superficial, de $0-0.2 \mathrm{~m}$, de nove solos, escolhidas por apresentarem variação no material de origem, as quais contemplaram as Ordens Latossolo, Nitossolo, Argissolo e Neossolo. Para determinar a quantidade de B adsorvido amostras com e sem calagem, após incubadas durante 40 dias, foram mantidas em contato, mediante agitação por $24 \mathrm{~h}$, com solução de $\mathrm{CaCl}_{2} 0,01 \mathrm{~mol} \mathrm{~L}^{-1}$ contendo diferentes concentrações de $\mathrm{B}\left(0,1,2,4,8\right.$ e $16 \mathrm{mg} \mathrm{L}^{-1}$ de $\left.\mathrm{B}\right)$. O ajuste dos resultados experimentais foi realizado pela forma não-linear da isoterma de Langmuir. A adsorção máxima de $\mathrm{B}$ variou de 2,28 a 42,89 mg kg-1 (sem calagem) e de 22,73 a 109,89 $\mathrm{mg} \mathrm{kg}^{-1}$ (com calagem), sendo que, os Nitossolos foram os solos que apresentaram maior capacidade de adsorção de B. A calagem aumentou a quantidade de B adsorvido nos solos, exceto no Latossolo Vermelho-Amarelo e no Argissolo Vermelho-Amarelo. A energia de ligação de $\mathrm{B}$ no solo diminuiu com a calagem, na maioria dos solos, indicando que em valores de $\mathrm{pH}$ mais elevados a $\mathrm{B}$ é adsorvida mais fracamente. $\mathrm{O} \mathrm{pH}$ do solo, a matéria orgânica e os teores de óxidos de silício $\left(\mathrm{SiO}_{2}\right)$ e de alumínio $\left(\mathrm{Al}_{2} \mathrm{O}_{3}\right)$ foram as propriedades do solo que se correlacionaram diretamente com a adsorção de B.

Palavras-chave: Isoterma de Langmuir, capacidade de adsorção máxima, calagem, adubação boratada

${ }^{1}$ Profa. Centro de Ciências Agrárias, Universidade Estadual do Oeste do Paraná, UNIOESTE. Marechal Cândido Rondon, PR. E-mail: maria.lana@unioeste.br

${ }^{2}$ Profs. do Curso de Agronomia, Faculdades Integradas de Ourinhos, FIO, Ourinhos, SP. E-mail: fsteiner_agro@yahoo.com.br; tiagozoz@fca.unesp.br

${ }^{3}$ Dr. Técnico do Laboratório de Fertilidade do Solo e Nutrição Mineral de Plantas, UNIOESTE. Marechal Cândido Rondon, PR. E-mail: juceneiff@hotmail.com

${ }^{4}$ Dr. Bolsista Pesquisador PNPD-CAPES, UNIOESTE. Marechal Cândido Rondon, PR. E-mail: rubensfey@hotmail.com

* Author for correspondence 


\section{Introduction}

Boron (B) deficiency in soil poses a serious limitation to the development of several economicinterest crops, due to natural soil's low fertility, removal by crops and inappropriate or excessive use of acidity corrective that contribute to its insolubilization. In addition, the appropriate management of B in soil-plant system is usually difficult because the range of $\mathrm{B}$ concentrations in soil solution between those that causes deficiency or toxicity symptoms in plants is relatively narrow. Thus, prediction of $\mathrm{B}$ concentration in soil solution is particularly important.

The availability of B depends upon adsorptiondesorption processes, which are influenced by various physicochemical properties of soils (ARORA; CHAHAL, 2010). The extent of B adsorption in soil depends of solution $\mathrm{pH}$, soil texture and mineral composition (COMMUNAR; KEREN, 2006). Of these, the soil $\mathrm{pH}$ has been reported as the main factor affecting the $\mathrm{B}$ adsorption in the soil (SALTALI et al., 2005; SOARES; CASAGRANDE; ALLEONI, 2008; CHEN; HO; LEE, 2009), mainly by influencing in the control of the predominant $\mathrm{B}$ species in solution and attributes related to its adsorption such as charge balance on colloids surface. Other factors, such as the clay content, aluminium and iron (hydr)oxides, clay minerals, calcium carbonate and organic matter of soil also influence B sorption in agricultural soils (GOLDBERG; CORWIN; SUAREZ, 2005; ARORA; CHAHAL, 2007; GOLDBERG; SUAREZ; SHOUSE, 2008; SHAFIQ et al., 2008; ARORA; CHAHAL, 2010; STEINER et al., 2012). Several possible mechanisms for the chemical combination of B with soils include anion exchange, precipitation of insoluble borates with sesquioxides, sorption of borate ions or molecular boric acid, formation of organic complexes, and fixation of B in the clay lattice (KEREN; BINGHAM, 1985).

Boron adsorption increases with increasing $\mathrm{pH}$ and reaches a maximum around $\mathrm{pH} 9.0$ and decreases with further increase in $\mathrm{pH}$ (GOLDBERG, 1997). The maximum development of adsorption sites occurs at a $\mathrm{pH}$ equivalent to the dissociation constant (pKa) of boric acid, approximately 9.2. At below $\mathrm{pH} 7.0, \mathrm{~B}(\mathrm{OH})_{3}{ }^{0}$ predominated, but because the affinity of the clay from this species is relatively low, the amount of adsorption is small. As the $\mathrm{pH}$ increased, the $\mathrm{B}(\mathrm{OH})_{4}^{-}$concentration increased rapidly. The amount of adsorbed $\mathrm{B}$ increased rapidly because of the relatively strong affinity of the clays. Further, increase in $\mathrm{pH}$ resulted in an enhanced $\mathrm{OH}^{-}$ concentration relative $\mathrm{B}(\mathrm{OH})_{4}^{-}$, and $\mathrm{B}$ adsorption decreased rapidly due to the competition of $\mathrm{OH}^{-}$ for the adsorption sites (GOLDBERG; CORWIN; SUAREZ, 2005).

The agricultural practice that is most often used to raise soil $\mathrm{pH}$ is liming. Thus, it is expected that the acidity correction in soil until $\mathrm{pH} 6.0$, as recommended for most crops, increases the $\mathrm{B}$ adsorption in the soil. In a clayey Rhodic Hapludox of Mato Grosso State, Brazil, Rosolem and Bíscaro (2007) found that the application of $9.0 \mathrm{Mg} \mathrm{ha}^{-1}$ lime incorporated in the $0-20 \mathrm{~cm}$ layer increased seven times the maximum amount of adsorbed B in the first year.

Various models can describe adsorption reactions. Boron adsorption by soils has been described using empirical models such as Langmuir and Freundlich adsorption isotherm equations (GOLDBERG, 2003). These adsorption isotherms take into account intensity, quantity and capacity factors, which are important for predicting the amount of soil nutrient required for maximum plant growth. The Langmuir equation is more attractive for providing coefficients which quantify the maximum adsorption capacity (MAC) and bonding energy (K) and had its successful use on predicting of the B adsorption in different Brazilian soils (ALLEONI; CAMARGO, 2000; SOARES; ALLEONI; CASAGRANDE, 2005; SOARES; CASAGRANDE; ALLEONI, 2008; STEINER et al., 2012).

The present study investigated the effect of 
liming on B adsorption in different soils of Paraná State, and to correlate these values with some physical and chemical properties of the soils.

\section{Material and Methods}

Surface samples $(0-0.2 \mathrm{~m})$ from nine soils of Paraná State, Brazil, were selected for B adsorption studies (Table 1). The physical and chemical properties of the soils were determined by adopting standard procedures, and some properties are shown in Table 2. Soil $\mathrm{pH}$ in water was determined potentiometrically in a 1:2.5 (soil:water) suspension using a combined calomel reference glass electrode and $\mathrm{pH}$ meter. Organic matter was quantified by oxidation with potassium dichromate in the presence of sulfuric acid, followed by titration with ammonium Fe(II) sulfate (EMBRAPA, 1997). Hot water soluble $\mathrm{B}$ was determined by the azomethine- $\mathrm{H}$ method (ABREU; ABREU; ANDRADE, 2001).
Basic cations $\left(\mathrm{Ca}^{2+}, \mathrm{Mg}^{2+}\right.$ and $\left.\mathrm{K}^{+}\right)$were extracted by ion exchange resin and determined by atomic absorption spectrophotometry. Exchangeable Al was extracted by $1 \mathrm{~mol} \mathrm{~L}^{-1} \mathrm{KCl}$ solution and determined by titration with $0.025 \mathrm{~mol} \mathrm{~L}^{-1} \mathrm{NaOH}$. Cation exchange capacity (CEC) was estimated by the summation method $(\mathrm{CEC}=\mathrm{Ca}+\mathrm{Mg}+\mathrm{K})$. The $\mathrm{Fe}$ and $\mathrm{Al}$ was extracted using a $9 \mathrm{~mol} \mathrm{~L}^{-1} \mathrm{H}_{2} \mathrm{SO}_{4}$ solution (1:20 soil:solution ratio), and $\mathrm{Si}$ was removed with $\mathrm{NaOH}$ from the residue of the acid attack. Contents of $\mathrm{Fe}$ and $\mathrm{Al}$ were determined using flame atomic absorption spectrophotometry and $\mathrm{Si}$ was quantified by gravimetry, and expressed in the form of oxides to calculate the weathering index by the molar ratio $\mathrm{Ki}=\left(\% \mathrm{SiO}_{2} / 60\right) /\left(\% \mathrm{Al}_{2} \mathrm{O}_{3} / 102\right)$ (EMBRAPA, 1997). Particle size analysis was performed by the pipette method (EMBRAPA, 1997), based on decantation speed of different soil particles after dispersion in $0.015 \mathrm{~mol} \mathrm{~L}^{-1}\left(\mathrm{NaPO}_{3}\right)_{6}$. $\mathrm{NaO} / 1 \mathrm{~mol} \mathrm{~L}^{-1} \mathrm{NaOH}$ by overnight shaking.

Table 1. Brazilian soil classification, approximate equivalence to soil taxonomy, parent material and sampling site of the nine soils from Paraná State.

\begin{tabular}{|c|c|c|c|c|}
\hline Soil & Brazilian soil classification $^{\dagger}$ & US taxonomy ${ }^{\dagger \dagger}$ & Parent material & $\begin{array}{c}\text { Geographical } \\
\text { coordinates }\end{array}$ \\
\hline Ox1 & Red Latosol & Rhodic Acrudox & Basalt & $24^{\circ} 32^{\prime} \mathrm{S}, 54^{\circ} 01^{\prime} \mathrm{W}$ \\
\hline Ox2 & Red Latosol & Rhodic Hapludox & Shale & $25^{\circ} 09^{\prime} \mathrm{S}, 50^{\circ} 09^{\prime} \mathrm{W}$ \\
\hline Ox3 & Red-Yellow Latosol & Typic Hapludox & Caiuá sandstone & $23^{\circ} 48^{\prime} \mathrm{S}, 53^{\circ} 15^{\prime} \mathrm{W}$ \\
\hline Ox4 & Red-Yellow Latosol & Typic Hapludox & Furnas sandstone & $25^{\circ} 06^{\prime} \mathrm{S}, 50^{\circ} 03^{\prime} \mathrm{W}$ \\
\hline Alf1 & Red Nitosol & Arenic Hapludalf & Basalt & $24^{\circ} 36^{\prime} \mathrm{S}, 54^{\circ} 04^{\prime} \mathrm{W}$ \\
\hline Alf2 & Red Nitosol & Arenic Hapludalf & Shale & $25^{\circ} 10^{\prime} \mathrm{S}, 50^{\circ} 09^{\prime} \mathrm{W}$ \\
\hline Ult1 & Red-Yellow Argisol & Arenic Hapludult & Caiuá sandstone & $23^{\circ} 48^{\prime} \mathrm{S}, 53^{\circ} 15^{\prime} \mathrm{W}$ \\
\hline Ult2 & Red-Yellow Argisol & Arenic Hapludult & Basalt & $24^{\circ} 24^{\prime} \mathrm{S}, 54^{\circ} 07^{\prime} \mathrm{W}$ \\
\hline Ent & Regolithic Neosol & Typic Usthorthent & Basalt & $24^{\circ} 37^{\prime} \mathrm{S}, 54^{\circ} 04^{\prime} \mathrm{W}$ \\
\hline
\end{tabular}

According to Embrapa (2006). ${ }^{\dagger}$ USDA Soil Taxonomy (Soil Survey Staff, 2010).

Source: Elaboration of the authors.

To evaluate the effect of liming on B adsorption, soil subsamples received the application of calcium carbonate amount equivalent to increase the base saturation to $70 \%$. These subsamples were maintained at field capacity $(0.03 \mathrm{MPa})$ for 60 days. After this period, soil samples were air-dried, crushed, and sieved to pass a $2-\mathrm{mm}$ mesh screen. Soil $\mathrm{pH}$ was determined with an electrode on a 1:2.5 (w/v) soil-to-water solution. 
Table 2. Some physical and chemical properties of the soils used.

\begin{tabular}{|c|c|c|c|c|c|c|c|c|c|c|c|c|}
\hline Soil & $\begin{array}{c}\mathrm{pH} \\
\text { initial } \\
\end{array}$ & $\begin{array}{c}\mathrm{pH} \text { after } \\
\text { liming }\end{array}$ & $\mathrm{OM}$ & $\mathrm{Al}$ & $\mathrm{CEC}$ & $\mathrm{B}$ & Clay & $\mathrm{SiO}_{2}$ & $\mathrm{Fe}_{2} \mathrm{O}_{3}$ & $\mathrm{Al}_{2} \mathrm{O}_{3}$ & $\mathrm{TiO}_{2}$ & $\mathrm{Ki}$ \\
\hline & & & $\mathrm{g} \mathrm{kg}^{-1}$ & \multicolumn{2}{|c|}{$\mathrm{mmol}_{\mathrm{c}} \mathrm{dm}^{-3}$} & $\mathrm{mg} \mathrm{dm}^{-3}$ & \multicolumn{6}{|c|}{ 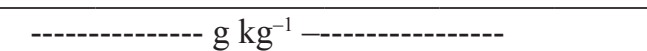 } \\
\hline Ox1 & 4.6 & 6.0 & 22.7 & 5.5 & 149 & 0.16 & 620 & 234 & 198 & 223 & 394 & 1.79 \\
\hline Ox2 & 3.8 & 6.6 & 21.3 & 7.5 & 141 & 0.29 & 785 & 101 & 97 & 264 & 101 & 0.65 \\
\hline Ox3 & 4.9 & 7.4 & 20.3 & 2.0 & 129 & 0.48 & 250 & 65 & 38 & 75 & 107 & 1.47 \\
\hline Ox4 & 4.2 & 6.1 & 29.4 & 4.5 & 131 & 0.51 & 315 & 41 & 33 & 109 & 44 & 0.64 \\
\hline Alf1 & 5.2 & 7.3 & 32.7 & 1.5 & 157 & 0.33 & 550 & 209 & 169 & 179 & 437 & 1.98 \\
\hline Alf2 & 3.9 & 6.9 & 41.8 & 11.0 & 161 & 0.65 & 780 & 117 & 78 & 220 & 114 & 0.90 \\
\hline Ult1 & 5.2 & 6.6 & 9.1 & 1.5 & 64 & 0.39 & 85 & 18 & 24 & 28 & 67 & 1.11 \\
\hline Ult2 & 3.7 & 6.4 & 30.0 & 33.5 & 166 & 0.76 & 700 & 206 & 162 & 197 & 34 & 1.78 \\
\hline Ent & 5.1 & 6.5 & 15.7 & 1.5 & 153 & 0.47 & 635 & 221 & 196 & 153 & 289 & 2.46 \\
\hline
\end{tabular}

OM: Organic matter. CEC: cation exchange capacity. Ki: weathering index calculated by the molar ratio $\mathrm{SiO}_{2} / \mathrm{Al}_{2} \mathrm{O}_{3}$.

Source: Elaboration of the authors.

Adsorption experiments were carried out in triplicate using a batch technique. About $4.0 \mathrm{~g}$ of soil was shaken, in polyethylene tubes, for 24 hours at $24 \pm 2{ }^{\circ} \mathrm{C}$, with $20 \mathrm{~mL} 0.01 \mathrm{~mol} \mathrm{~L}^{-1} \mathrm{CaCl}_{2}$ solution containing $\mathrm{B}$ concentrations of $0,1,2,4,8$ and $16 \mathrm{mg}$ $\mathrm{L}^{-1}$ as boric acid, equivalent to $0,5,10,20,40$ and 80 mg B kg-1 soil, respectively. After shaking, the soil solution was filtered through Whatman $\mathrm{N}^{\circ} 42$ filter paper (SOARES; CASAGRANDE, 2009). Boron concentration in the filtrate was determined by the Azomethine-H method using a spectrophotometer at $420 \mathrm{~nm}$ wave length, as previously described by Abreu, Abreu and Andrade (2001).

The amount of $\mathrm{B}$ adsorbed, $[\mathrm{B}]_{\mathrm{ads}}$, and the adsorption percentage, $\% \mathrm{~B}_{\text {ads }}$, were calculated by the following ratios, respectively:

$$
\begin{aligned}
& {[\mathrm{B}]_{\mathrm{ads}}=\left[\left(\mathrm{C}_{0}-\mathrm{C}_{\mathrm{eq}}\right) \mathrm{V}\right] / \mathrm{m}} \\
& \% \mathrm{~B}_{\mathrm{ads}}=\left[\left(\mathrm{C}_{0}-\mathrm{C}_{\mathrm{eq}}\right) / \mathrm{C}_{0}\right] \times 100
\end{aligned}
$$

where $[\mathrm{B}]_{\mathrm{ads}}$ is the amount of adsorbed $\mathrm{B}$ after equilibrium ( $\mathrm{mg} \mathrm{B} \mathrm{kg}{ }^{-1}$ soil); $\mathrm{C}_{0}$ and $\mathrm{C}_{\mathrm{eq}}$ are the initial added and equilibrium concentrations (mg B $\left.\mathrm{L}^{-1}\right)$, respectively; $\mathrm{V}=$ solution volume $(\mathrm{mL})$; and $\mathrm{m}=$ mass of the soil sample $(\mathrm{g})$. The amount of $\mathrm{B}$ initially present in soil (Table 2), although small, was discounted in the calculation of the amount of adsorbed B.

Adsorption isotherms $\left([\mathrm{B}]_{\mathrm{ads}}\right.$ vs. $\left.\mathrm{C}_{\mathrm{eq}}\right)$ were fitted from the experimental results, and the $\mathrm{B}$ adsorption was compared with that estimated by the non-linear form of the Langmuir isotherm:

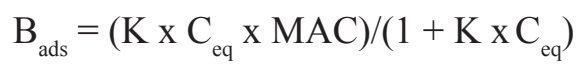

where $\mathrm{K}$ is the constant related to bonding energy of $\mathrm{B}$ to the soil $\left(\mathrm{L} \mathrm{mg}^{-1}\right)$ and MAC is the maximum adsorption capacity of soil (mg $\mathrm{B} \mathrm{kg} \mathrm{kg}^{-1}$ soil). Langmuir isotherm was fitted to the B adsorption results by the Fitfunc program (BARROW, 1987), which uses the non-linear optimization of the least squares and does not require the linearization of the isotherm, that avoids both the introduction of changes in the error distribution and the acquisition of influenced parameters (K and MAC) (SOARES; ALLEONI; CASAGRANDE, 2005).

The experiment was designed to be completely randomized. The effect of liming on MAC and $\mathrm{K}$ were compared by $\mathrm{F}$ test at the 0.05 level of confidence. Comparison among soils was made based on the maximum adsorption values. Simple linear correlation analysis was performed to detect 
the physical and chemical properties of soil that correlated with the constant of Langmuir adsorption (MAC and $\mathrm{K}$ ) and adsorption after addition of 2.0 mg L ${ }^{-1}$ B (ALLEONI; CAMARGO, 2000).

\section{Results and Discussion}

\section{Soil characterization}

The soil $\mathrm{pH}$ value ranged from 3.7 to 5.2 (without liming) and from 6.0 to 7.4 (with liming) (Table 2). Organic matter (OM) content was higher than $15 \mathrm{~g} \mathrm{~kg}^{-1}$ for the majority of samples, except for the Arenic Hapludult (Ult1). The Arenic Hapludalf had the highest contents of OM (41.8 g $\mathrm{kg}^{-1}$ ). Most of the soil samples had high levels of hot water soluble B (B content $\geq 0.30 \mathrm{mg} \mathrm{dm}^{-3}$ ) (Table 2). Rhodic Acrudox, Rhodic Hapludox, Arenic Hapludalf, Arenic Hapludult and Typic Usthorthent were very clayey (> $600 \mathrm{~g} \mathrm{~kg}^{-1}$ clay), while Arenic Hapludalf (Alf1) was clayey (350-600 $\mathrm{g} \mathrm{kg}^{-1}$ ). On the other hand, the Typic Hapludox (Ox3) and Typic Hapludox (Ox3) were medium-textured (150-350 g $\mathrm{kg}^{-1}$ clay) and Arenic Hapludult (Ult1) was sandy $(<$ $150 \mathrm{~g} \mathrm{~kg}^{-1}$ clay) (Table 2).

\section{Boron adsorption by soils}

The amount of adsorbed B increased with increasing concentration of added B. However, the proportion of adsorbed B was gradually less in the more concentrated solutions (Table 3). Similar results have also been reported by other authors (ALLEONI; CAMARGO, 2000; GOLDBERG, 2003; SHAFIQ et al., 2008). The relatively low increase as the solution becomes more concentrated occurs due to saturation of the adsorbent surface in heterogeneous systems (GOLDBERG; FORSTER; HEICK, 1993).

The amount of adsorbed $\mathrm{B}$ ranged from 0.8 to $28.5 \mathrm{mg} \mathrm{kg}^{-1}$ and 1.2 to $42.2 \mathrm{mg} \mathrm{kg}^{-1}$ in soils without and with liming, respectively (Table 3 ), which are similar to the values normally found in the literature. In tropical soils from São Paulo State, Alleoni and Camargo (2000) using the same B concentrations, found adsorbed $B$ values from 0.6 to $11.1 \mathrm{mg} \mathrm{kg}^{-1}$ soil regardless of liming. In a Rhodic Hapludox of Mato Grosso State, Brazil, Rosolem and Bíscaro (2007) found adsorbed B values of 9.5 and $24.2 \mathrm{mg}$ $\mathrm{kg}^{-1}$ after the first year of application of 1.5 and 9.0 $\mathrm{Mg} \mathrm{ha}^{-1}$ lime. In calcareous soils of Pakistan, Shafiq et al. (2008) found higher adsorbed B values from 5.5 to $108.0 \mathrm{mg} \mathrm{kg}^{-1}$.

Liming increased the amount of adsorbed B in the majority soils (Table 3). There was a mean increase in the amount of adsorbed B by soils of $36 \%$. The greatest increase was observed in the Arenic Hapludalf (Alf2) and Arenic Hapludult (Ult1) both with increase of $57 \%$, followed by soils Typic Hapludox - Ox3 (52\%), Typic Usthorthent - Ent (47\%), Arenic Hapludalf - Alf1 (45\%) and Rhodic Acrudox - Ox1 (41\%), while that the soils Rhodic Hapludox (Ox2), Arenic Hapludult (Ult2) and Typic Hapludox (Ox4) were little affected by liming, with increases of less than $15 \%$. A mean increase in the order of $33 \% \mathrm{~B}$ adsorption after calcium carbonate application was observed in tropical soils by Alleoni and Camargo (2000). 
Table 3. Boron concentration in the equilibrium solution ( $\left.\mathrm{mg} \mathrm{B} \mathrm{L}^{-1}\right)$, amount of absorbed $\mathrm{B}\left(\mathrm{mg} \mathrm{B} \mathrm{kg}^{-1}\right.$ soil), and percentage of adsorbed B in nine soils of Paraná State with and without liming, as a function of added boron.

\begin{tabular}{|c|c|c|c|c|c|c|c|}
\hline \multirow{2}{*}{ Soil } & \multirow{2}{*}{$\begin{array}{l}\text { Boron } \\
\text { added }\end{array}$} & \multicolumn{2}{|c|}{ Boron in equilibrium solution } & \multicolumn{4}{|c|}{ Boron adsorbed in the soil } \\
\hline & & Without lime & With lime & Without lime & With lime & Without lime & With lime \\
\hline & \multicolumn{3}{|c|}{ - mg B L $^{-1}$} & \multicolumn{2}{|c|}{--- $\mathrm{mg} \mathrm{B} \mathrm{kg}^{-1}$ soil --- } & \multicolumn{2}{|c|}{--- \% --- } \\
\hline & 1 & 0.58 & 0.41 & 2.0 & 2.5 & 42 & 59 \\
\hline & 2 & 1.22 & 0.84 & 3.8 & 5.6 & 39 & 58 \\
\hline \multirow[t]{5}{*}{ Ox1 } & 4 & 2.80 & 2.02 & 5.8 & 10.1 & 30 & 49 \\
\hline & 8 & 6.41 & 4.45 & 7.7 & 17.4 & 20 & 44 \\
\hline & 16 & 13.35 & 10.27 & 12.7 & 30.0 & 17 & 36 \\
\hline & 1 & 0.52 & 0.47 & 2.3 & 2.3 & 48 & 53 \\
\hline & 2 & 1.15 & 1.06 & 4.1 & 4.6 & 43 & 47 \\
\hline \multirow[t]{5}{*}{ Ox2 } & 4 & 2,25 & 2.23 & 8.4 & 8.3 & 44 & 44 \\
\hline & 8 & 5.38 & 4.77 & 12.4 & 15.5 & 33 & 40 \\
\hline & 16 & 12.82 & 10.53 & 14.4 & 24.5 & 20 & 34 \\
\hline & 1 & 0.70 & 0.66 & 1.5 & 1.5 & 30 & 34 \\
\hline & 2 & 1.58 & 1.33 & 2.1 & 3.1 & 21 & 33 \\
\hline \multirow[t]{5}{*}{ Ox3 } & 4 & 3.53 & 2.72 & 2.3 & 5.8 & 12 & 32 \\
\hline & 8 & 7.49 & 5.51 & 2.4 & 11.4 & 6 & 31 \\
\hline & 16 & 15.34 & 11.79 & 3.2 & 19.7 & 4 & 26 \\
\hline & 1 & 0.54 & 0.50 & 2.1 & 2.3 & 46 & 50 \\
\hline & 2 & 1.16 & 1.13 & 3.9 & 4.1 & 42 & 43 \\
\hline \multirow[t]{5}{*}{ Ox4 } & 4 & 2.42 & 2.27 & 7.2 & 7.6 & 40 & 43 \\
\hline & 8 & 4.96 & 4.84 & 12.5 & 14.4 & 38 & 39 \\
\hline & 16 & 11.03 & 10.68 & 21.3 & 22.3 & 31 & 33 \\
\hline & 1 & 0.36 & 0.32 & 3.0 & 3.2 & 64 & 68 \\
\hline & 2 & 1.18 & 0.59 & 3.9 & 6.5 & 41 & 70 \\
\hline \multirow[t]{5}{*}{ Alf1 } & 4 & 2.36 & 1.22 & 7.8 & 13.0 & 41 & 69 \\
\hline & 8 & 6.08 & 2.70 & 8.9 & 23.2 & 24 & 66 \\
\hline & 16 & 13.97 & 6.50 & 9.5 & 42.2 & 13 & 59 \\
\hline & 1 & 0.65 & 0.31 & 1.8 & 3.2 & 35 & 69 \\
\hline & 2 & 1.39 & 0.62 & 3.0 & 6.6 & 31 & 69 \\
\hline \multirow[t]{5}{*}{ Alf2 } & 4 & 2.94 & 1.35 & 5.2 & 12.4 & 27 & 66 \\
\hline & 8 & 6.10 & 3.25 & 9.0 & 21.8 & 24 & 59 \\
\hline & 16 & 13.73 & 7.88 & 11.3 & 39.0 & 14 & 51 \\
\hline & 1 & 0.77 & 0.74 & 0.8 & 1.2 & 23 & 26 \\
\hline & 2 & 1.75 & 1.56 & 1.1 & 2.0 & 13 & 22 \\
\hline \multirow[t]{5}{*}{ Ult1 } & 4 & 3.61 & 3.14 & 1.6 & 3.8 & 10 & 21 \\
\hline & 8 & 7.53 & 6.43 & 2.0 & 6.9 & 6 & 20 \\
\hline & 16 & 15.53 & 13.53 & 2.1 & 10.8 & 3 & 15 \\
\hline & 1 & 0.34 & 0.36 & 3.3 & 3.1 & 66 & 64 \\
\hline & 2 & 0.69 & 0.72 & 6.1 & 6.1 & 65 & 64 \\
\hline \multirow[t]{5}{*}{ Ult2 } & 4 & 1.69 & 1.61 & 11.2 & 11.6 & 58 & 60 \\
\hline & 8 & 3.99 & 4.12 & 18.7 & 18.1 & 50 & 48 \\
\hline & 16 & 9.92 & 9.88 & 28.4 & 30.0 & 38 & 38 \\
\hline & 1 & 0.38 & 0.06 & 2.7 & 4.5 & 62 & 94 \\
\hline & 2 & 0.92 & 0.26 & 5.0 & 8.4 & 54 & 87 \\
\hline \multirow[t]{3}{*}{ Ent } & 4 & 2.32 & 1.04 & 7.9 & 13.8 & 42 & 74 \\
\hline & 8 & 5.44 & 3.18 & 12.1 & 23.9 & 32 & 60 \\
\hline & 16 & 13.24 & 8.84 & 12.5 & 35.1 & 17 & 45 \\
\hline
\end{tabular}

Source: Elaboration of the authors. 
The Langmuir model (hyperbolic Langmuir adsorption isotherms) fitted well to the values of adsorbed B in the soils with and without liming, across the range of $\mathrm{B}$ concentrations (with determination coefficients $\geq 0.97$ at $\mathrm{P}<0.01$ ) (Table 4). These results were expected since there is no record of deviations from the Langmuir equation at concentrations below $30 \mathrm{mg} \mathrm{L}^{-1}$ of $\mathrm{B}$ (ALLEONI; CAMARGO, 2000). The use of lower concentrations is best suited to represent the $\mathrm{B}$ amount contained in Brazilian soils (ALLEONI; CAMARGO; CASAGRANDE, 1998). These authors whilst investigating weathered Brazilian soils used $\mathrm{B}$ concentrations in the solution ranging from 0 to $16 \mathrm{mg} \mathrm{L}^{-1}$ and found that the results of $\mathrm{B}$ adsorption in soils were well fitted by the Langmuir isotherm. Other authors also pointed out the ability of the Langmuir isotherm to estimate the $\mathrm{B}$ adsorption by soils (ALLEONI; CAMARGO, 2000; SOARES; ALLEONI; CASAGRANDE, 2005; COMMUNAR; KEREN, 2006; SOARES; CASAGRANDE; ALLEONI, 2008; ARORA; CHAHAL, 2010; STEINER et al., 2012).

Table 4. Regression equations and determination coefficients $\left(\mathrm{R}^{2}\right)$ for the non-linear form of the Langmuir isotherm, maximum adsorption capacity of B (MAC), bonding energy of B to the soil (K) in nine soils of Paraná State with and without liming.

\begin{tabular}{|c|c|c|c|c|c|}
\hline \multirow{2}{*}{ Soil } & \multirow{2}{*}{ Liming } & \multirow{2}{*}{ Regression equation ${ }^{\dagger}$} & \multirow{2}{*}{$\mathrm{R}^{2}$} & \multicolumn{2}{|c|}{ Langmuir constants ${ }^{\dagger \dagger}$} \\
\hline & & & & MAC & $\mathrm{K}$ \\
\hline \multirow{3}{*}{ Ox1 } & & & & mg B kg-1 soil & $\mathrm{L} \mathrm{mg}^{-1}$ \\
\hline & Without & $\mathrm{B}_{\mathrm{ads}}=\left(3.3784 \mathrm{C}_{\mathrm{eq}}\right) /\left(1+0.2161 \mathrm{C}_{\mathrm{eq}}\right)$ & $0.97 * *$ & $16.4 \mathrm{~b}$ & $0.21 \mathrm{a}$ \\
\hline & With & $\mathrm{B}_{\mathrm{ads}}^{\mathrm{ads}}=\left(6.4935 \mathrm{C}_{\mathrm{eq}}^{\mathrm{eq}}\right) /\left(1+0.1234 \mathrm{C}_{\mathrm{eq}}\right)$ & $0.98 * *$ & $52.6 \mathrm{a}$ & $0.12 \mathrm{~b}$ \\
\hline \multirow{2}{*}{ Ox2 } & Without & $\mathrm{B}_{\mathrm{ads}}=\left(5.5556 \mathrm{C}_{\mathrm{eq}}\right) /\left(1+0.3000 \mathrm{C}_{\mathrm{eq}}\right)$ & $0.98 * *$ & $18.5 \mathrm{~b}$ & $0.30 \mathrm{a}$ \\
\hline & With & $\mathrm{B}_{\mathrm{ads}}=\left(4.8780 \mathrm{C}_{\mathrm{eq}}\right) /\left(1+0.1024 \mathrm{C}_{\mathrm{eq}}\right)$ & $0.99 * *$ & $47.6 \mathrm{a}$ & $0.10 \mathrm{~b}$ \\
\hline \multirow{2}{*}{ Ox3 } & Without & $\mathrm{B}_{\mathrm{ads}}=\left(2.4272 \mathrm{C}_{\mathrm{eq}}\right) /\left(1+0.7306 \mathrm{C}_{\mathrm{eq}}\right)$ & $0.98 * *$ & $3.3 \mathrm{~b}$ & $0.73 \mathrm{a}$ \\
\hline & With & $\mathrm{B}_{\mathrm{ads}}=\left(2.4096 \mathrm{C}_{\mathrm{eq}}\right) /\left(1+0.0361 \mathrm{C}_{\mathrm{eq}}\right)$ & $0.98 * *$ & $66.7 \mathrm{a}$ & $0.04 \mathrm{~b}$ \\
\hline \multirow{2}{*}{ Ox4 } & Without & $\mathrm{B}_{\mathrm{ads}}=\left(3.7594 \mathrm{C}_{\mathrm{eq}}\right) /\left(1+0.0865 \mathrm{C}_{\mathrm{eq}}\right)$ & $0.98 * *$ & $42.9 \mathrm{a}$ & $0.08 \mathrm{a}$ \\
\hline & With & $\mathrm{B}_{\mathrm{ads}}=\left(4.3668 \mathrm{C}_{\mathrm{eq}}^{\mathrm{q}}\right) /\left(1+0.1004 \mathrm{C}_{\mathrm{eq}}\right)$ & $0.97 * *$ & $43,5 \mathrm{a}$ & $0.10 \mathrm{a}$ \\
\hline \multirow{2}{*}{ Alf1 } & Without & $\mathrm{B}_{\mathrm{ads}}=\left(8,8495 \mathrm{C}_{\mathrm{eq}}\right) /\left(1+0,8496 \mathrm{C}_{\mathrm{eq}}\right)$ & $0.99 * *$ & $10,4 \mathrm{~b}$ & $0.85 \mathrm{a}$ \\
\hline & With & $\mathrm{B}_{\mathrm{ads}}=\left(11,3636 \mathrm{C}_{\mathrm{eq}}\right) /\left(1+0,1023 \mathrm{C}_{\mathrm{eq}}\right)$ & $0.97 * *$ & 109.9 a & $0.10 \mathrm{~b}$ \\
\hline \multirow{2}{*}{ Alf2 } & Without & $\mathrm{B}_{\mathrm{ads}}=\left(2.8736 \mathrm{C}_{\mathrm{eq}}\right) /\left(1+0.1782 \mathrm{C}_{\mathrm{eq}}\right)$ & $0.99 * *$ & $16.3 \mathrm{~b}$ & $0.18 \mathrm{a}$ \\
\hline & With & $\mathrm{B}_{\mathrm{ads}}=\left(10.9890 \mathrm{C}_{\mathrm{eq}}\right) /\left(1+0.1209 \mathrm{C}_{\mathrm{eq}}\right)$ & $0.98 * *$ & 90.9 a & $0.12 \mathrm{~b}$ \\
\hline \multirow{2}{*}{ Ult1 } & Without & $\mathrm{B}_{\mathrm{ads}}=\left(1.5337 \mathrm{C}_{\mathrm{eq}}\right) /\left(1+0.6718 \mathrm{C}_{\mathrm{eq}}\right)$ & $0.99 * *$ & $2.3 \mathrm{~b}$ & $0.67 \mathrm{a}$ \\
\hline & With & $\mathrm{B}_{\mathrm{ads}}=\left(1.5267 \mathrm{C}_{\mathrm{eq}}\right) /\left(1+0.0672 \mathrm{C}_{\mathrm{eq}}\right)$ & $0.97 * *$ & $22.7 \mathrm{a}$ & $0.07 \mathrm{~b}$ \\
\hline \multirow{2}{*}{ Ult2 } & Without & $\mathrm{B}_{\mathrm{ads}}=\left(10.4167 \mathrm{C}_{\mathrm{eq}}\right) /\left(1+0.2778 \mathrm{C}_{\mathrm{eq}}\right)$ & $0.98 * *$ & $38.5 \mathrm{a}$ & $0.28 \mathrm{a}$ \\
\hline & With & $\mathrm{B}_{\mathrm{ads}}=\left(9.2593 \mathrm{C}_{\mathrm{eq}}\right) /\left(1+0.2030 \mathrm{C}_{\mathrm{eq}}\right)$ & $0.98 * *$ & $43.5 \mathrm{a}$ & $0.20 \mathrm{~b}$ \\
\hline \multirow{2}{*}{ Ent } & Without & $\mathrm{B}_{\mathrm{ads}}=\left(9.0909 \mathrm{C}_{\mathrm{eq}}\right) /\left(1+0.6364 \mathrm{C}_{\mathrm{eq}}\right)$ & $0.99 * *$ & $14.3 \mathrm{~b}$ & $0.64 \mathrm{a}$ \\
\hline & With & $\mathrm{B}_{\mathrm{ads}}=\left(32.2581 \mathrm{C}_{\mathrm{e}}\right) /\left(1+0.8046 \mathrm{C}_{\mathrm{eg}}\right)$ & $0.97 * *$ & $40.0 \mathrm{a}$ & $0.80 \mathrm{a}$ \\
\hline
\end{tabular}

Non-linear equation of the Langmuir isotherm $\left[\mathrm{B}_{\mathrm{ads}}=\left(\mathrm{K} \times \mathrm{C}_{\mathrm{eq}} \times \mathrm{MAC}\right) /\left(1+\mathrm{K}_{\mathrm{x} \mathrm{C}} \mathrm{e}\right)\right]$. **: statistical significance at $1 \%$ by $\mathrm{F}$ test. ${ }^{\dagger}$ Values represented by the different letters, for each soil show significant differences $(\mathrm{F}$ test, $\mathrm{P}<0.05)$.

Source: Elaboration of the authors. 
The values of maximum adsorption capacity (MAC) and bonding energy constant $(\mathrm{K})$ estimated by the Langmuir isotherm (Table 3) were similar to those found in studies using a range similar to the $\mathrm{B}$ concentration added to the soil. The $\mathrm{K}$ ranged from 0.04 to $0.85 \mathrm{~L} \mathrm{mg}^{-1}$, while the MAC ranged from 2.3 to $109.9 \mathrm{mg} \mathrm{B} \mathrm{kg}^{-1}$ soil. The wide variation in these parameters can be attributed to differences in the physical, chemical and mineralogical properties of the soils, in addition to the increase in $\mathrm{pH}$ after liming. In tropical soils, Alleoni, Camargo and Casagrande (1998) and Alleoni and Camargo (2000) found similar $\mathrm{K}$ values $\left(0.06-1.16 \mathrm{~L} \mathrm{mg}^{-1}\right.$ ) and lower MAC values (2.5-15.8 $\left.\mathrm{mg} \mathrm{kg}^{-1}\right)$. On the other hand, in acric soils of São Paulo, Brazil, Soares, Casagrande and Alleoni (2008) found higher $\mathrm{K}$ values $\left(0.22\right.$ to $\left.2.13 \mathrm{~L} \mathrm{mg}^{-1}\right)$ and MAC (32.5 to $128.6 \mathrm{mg} \mathrm{kg}^{-1}$ ), which in turn were very close to the results reported by Shafiq et al. (2008) for calcareous soils of Pakistan.

Liming resulted in an increased MAC of B in the majority soils (Table 4). Maximum adsorption ranged from 2.3 to $42.9 \mathrm{mg} \mathrm{kg}^{-1}$ (without liming) and from 22.7 to $109.9 \mathrm{mg} \mathrm{kg}^{-1}$ (with liming). The maximum value of MAC, that is, $109.0 \mathrm{mg} \mathrm{B} \mathrm{kg}^{-1}$ soil, was observed in the Arenic Hapludalf (Alf1) followed by $90.9 \mathrm{mg} \mathrm{kg} \mathrm{kg}^{-1}$ in Arenic Hapludalf (Alf2), $66.7 \mathrm{mg} \mathrm{kg}^{-1}$ in Typic Hapludox (Ox3), and $52.6 \mathrm{mg} \mathrm{kg}^{-1}$ in Rhodic Hapludox (Ox1) (Table 4). The highest values of the MAC of B found in Arenic Hapludalf soils (Alf1 and Alf2) were due to the higher clay and organic matter contents of these soils. The increase of MAC of B verified after liming is due to the increased of soil $\mathrm{pH}$. Boron adsorption is highly influenced by $\mathrm{pH}$, increasing as the $\mathrm{pH}$ increases, attaining a maximum in $\mathrm{pH}$ around 9.0 and diminishing abruptly at high $\mathrm{pH}$ (GOLDBERG; CORWIN; SUAREZ, 2005). However, Rosolem and Bíscaro (2007) found that even by applying relatively high rates of lime, the $B$ adsorption by soil is only significant in the year that the liming was carried out, so that over time a greater amount of B remains in the soil solution under conditions of being readily taken up by plants or even being lost by leaching. Chen, Ho and Lee (2009) observed that soil re-acidification caused an increase in B desorption, increasing the element's content in solution. Indicating that B adsorption by soils submitted to liming is characterized by a rapid and reversible chemical reaction between the adsorbed and soluble B. This suggests that liming cause B deficiency only in soils with initial level near the limit of deficiency.

The bonding energy (K) decreased with the liming in most soils (Table 4). Indicating that at higher $\mathrm{pH}$ values the $\mathrm{B}$ is adsorbed more weakly. This decrease on bonding energy can be explained by the increased surface charge of soil particles with increasing $\mathrm{pH}$, increasing the repulsion of $\mathrm{B}$ and then reducing the bonding energy of these particles.

\section{Effect of soil properties on B adsorption}

The MAC of B did not present a statistically significant correlation with most of the soil chemical properties - i.e., clay content, soluble B, exchangeable aluminum, cation exchange capacity (CEC), silicon $\left(\mathrm{SiO}_{2}\right)$, iron $\left(\mathrm{Fe}_{2} \mathrm{O}_{3}\right)$ and aluminum $\left(\mathrm{Al}_{2} \mathrm{O}_{3}\right)$ oxides and weathering index (Ki) (Table 5). These results indicate that these properties, in isolated form, have no effect on MAC of B in Paraná soils. The absence of correlation between the MAC and CEC can be explained due to this variable depends on other soil properties - e.g., organic matter and clay content. The CEC cannot theoretically contribute to adsorption of negatively charged species, such as $\mathrm{B}(\mathrm{OH})_{4}^{-}$. 
Table 5. Correlation coefficients of simple linear regression analysis between parameters of Langmuir adsorption isotherms (MAC and $\mathrm{K}$ ) and adsorption after addition of $2.0 \mathrm{mg} \mathrm{L}^{-1} \mathrm{~B}$ and some soil properties with and without liming.

\begin{tabular}{lcccccc}
\hline \multirow{2}{*}{$\begin{array}{l}\text { Soil } \\
\text { characteristics }\end{array}$} & \multicolumn{2}{c}{$\begin{array}{c}\text { Maximum adsorption capacity } \\
\text { (MAC) }\end{array}$} & \multicolumn{2}{c}{$\begin{array}{c}\text { Bonding energy } \\
(\mathrm{K})\end{array}$} & \multicolumn{2}{c}{$\begin{array}{c}\text { Adsorption after addition of } \\
2.0 \mathrm{mg} \mathrm{B} \mathrm{L}^{-1}\end{array}$} \\
\cline { 2 - 6 } & Without lime & With lime & Without lime & With lime & Without lime & With lime \\
\hline Soil pH & 0.56 & $0.83^{* *}$ & $0.87^{* *}$ & -0.42 & -0.47 & -0.11 \\
Clay & 0.11 & -0.04 & -0.23 & 0.46 & 0.52 & 0.55 \\
OM & 0.52 & $0.72^{*}$ & -0.47 & -0.24 & 0.32 & 0.42 \\
Soluble B & 0.32 & 0.12 & 0.32 & 0.43 & 0.52 & 0.21 \\
Ex. Al & 0.16 & 0.53 & 0.21 & 0.18 & -0.38 & 0.30 \\
$\mathrm{CEC}$ & 0.36 & 0.40 & 0.23 & 0.34 & 0.63 & 0.56 \\
$\mathrm{SiO}_{2}$ & -0.02 & 0.03 & 0.28 & $0.68^{*}$ & 0.60 & $0.68^{*}$ \\
$\mathrm{Fe}_{2} \mathrm{O}_{3}$ & 0.20 & 0.10 & -0.32 & 0.24 & 0.54 & 0.50 \\
$\mathrm{Al}_{2} \mathrm{O}_{3}$ & -0.04 & -0.07 & 0.30 & $0.74^{*}$ & $0.69 *$ & $0.65^{*}$ \\
$\mathrm{Ki}$ & -0.28 & 0.03 & $0.65^{*}$ & $0.69^{*}$ & 0.34 & 0.52 \\
\hline
\end{tabular}

OM: organic matter. Ex. Al: Exchangeable aluminum.CEC: cation exchange capacity. $\mathrm{SiO}_{2}, \mathrm{Fe}_{2} \mathrm{O}_{3}$ and $\mathrm{Al}_{2} \mathrm{O}_{3}$ : silicon, iron and aluminum oxides, respectively. Ki: weathering index calculated by the molar ratio $\mathrm{SiO}_{2} / \mathrm{Al}_{2} \mathrm{O}_{3}$. $*: \mathrm{P}<0.05$. **: $\mathrm{P}<0.01$.

Source: Elaboration of the authors.

Boron adsorption as a function of soil $\mathrm{pH}$ has a maximum value between 8.0 and 9.0 (GOLDBERG; SUAREZ; SHOUSE, 2008), which may explain the absence of correlation, in samples without liming, since the initial soil $\mathrm{pH}$ reached only 5.2 (Table 2). In limed soils, the $\mathrm{pH}$ reached values of 7.4 (Table 2), which allowed the existence of significant correlation with MAC of B (Table 5). These findings show that the isolated effect of the soil $\mathrm{pH}$ on $\mathrm{B}$ sorption seems to be relatively small in acid soils. Alleoni and Camargo (2000) studied soils with $\mathrm{pH}$ varying from 3.5 to 5.5 , and also did not obtain correlation with adsorbed B in São Paulo soils. It is important to note that, in the acid range, B is predominantly in the form of boric acid and not in its ionic form $\mathrm{B}(\mathrm{OH})_{4}^{-}$(GOLDBERG, 1997).

The correlation coefficient between the MAC of $\mathrm{B}$ and organic matter content was significant $(r=0.72 *)$ in the limed soil samples (Table 5). This finding corresponds to the results obtained by other researchers (ARORA; BHARDWAJ; SHARMA, 2002; SHARMA et al., 2006; ARORA; CHAHAL, 2010). Organic matter is an important soil factor affecting the availability of $\mathrm{B}$. Humus extracted from a soil retained significant amounts of $\mathrm{B}$ and was considered to play an important role in B adsorption (YERMIYAHU; KEREN; CHEN, 1995). Chaudhary and Shukla (2004) reported that organic carbon exerted a beneficial effect on the B sorption capacity of soils, which could be due to the formation of a complex between dihydroxy-organic compounds and $\mathrm{B}$. The presence of organic materials can also occlude the $\mathrm{B}$ reactive adsorption sites on soils (GOLDBERG, 1997). A possible mechanism for B sorption on organic matter is ligand exchange. Moreover, it has been suggested that the formation of the B-diol complexes was associated with the breakdown products of soil organic matter.

Silicon $\left(\mathrm{SiO}_{2}\right)$ and aluminum oxides $\left(\mathrm{Al}_{2} \mathrm{O}_{3}\right)$ were significantly correlated with the $\mathrm{B}$ adsorption after addition of $2.0 \mathrm{mg} \mathrm{B} \mathrm{L} \mathrm{B}^{-1}$ (Table 5). This finding corresponds to the results obtained by other researchers (ALLEONI; CAMARGO, 2000). The higher correlation coefficients are expected with Al oxides than with Fe oxides, due to the high affinity of $\mathrm{B}$ with the $\mathrm{OH}$ groups of $\mathrm{Al}$ (hydr)oxides and the higher specific surface (GOLDBERG; GLAUBIG, 1985). 
The bonding energy of $\mathrm{B}$ to the soil $(\mathrm{K})$ can provide insights into the mechanism most likely involved in $\mathrm{B}$ adsorption. The $\mathrm{K}$ values in the samples without liming were significantly correlated with soil $\mathrm{pH}\left(\mathrm{r}=0.87^{* *}\right)$ and weathering index ( $\mathrm{r}$ $=0.65^{*}$; Table 5 ). In the limed soil samples, the $\mathrm{K}$ values correlated positively with silicon oxides $(\mathrm{r}=$ $\left.0.68^{*}\right)$, aluminum oxides $\left(\mathrm{r}=0.74^{*}\right)$ and weathering index ( $\mathrm{r}=0.69 *$; Table 5). These findings indicate that the higher the value of these properties greater is the bonding energy of $\mathrm{B}$ to the soil.

\section{Conclusions}

The amount of adsorbed B by soils increased with increasing applied concentration; however the percentage of B adsorbed was decreased.

Liming increased the amount of B adsorbed in most soils used.

The bonding energy of $\mathrm{B}$ to the soil decreased with liming in most soils, indicating that at higher $\mathrm{pH}$ values the $\mathrm{B}$ is adsorbed more weakly.

The highest values of the maximum adsorption capacity of B were found in soils Arenic Hapludalf (Nitosol) due to the higher clay and organic matter contents of these soils.

Soil $\mathrm{pH}$, organic matter, and oxides of silicon and aluminum were the main soil properties that affected the B adsorption in Paraná soils.

\section{References}

ABREU, M. F.; ABREU, C. A.; ANDRADE, J. C. Determinação de boro em água quente usando aquecimento com microondas. In: RAIJ, B. van; ANDRADE, J. C.; CANTARELLA, H.; QUAGGIO, J. A. (Ed.). Análise química para avaliação da fertilidade de solos tropicais. Campinas: Instituto Agronômico, p. 231-239, 2001.

ALLEONI, L. R. F.; CAMARGO, O. A. Boron adsorption in soils from the State of São Paulo, Brazil. Pesquisa Agropecuária Brasileira, Brasília, v. 35, n. 2, p. 413-421, 2000.
ALLEONI,L.R.F.; CAMARGO,O.A.;CASAGRANDE, J. C. Isotermas de Langmuir e de Freundlich na descrição da adsorção de boro em solos altamente intemperizados. Scientia Agricola, Piracicaba, v. 55, n. 3, p. 379-387, 1998.

ARORA, H.; BHARDWAJ, S. S.; SHARMA, B. D. Effect of organic matter on boron adsorption by some soils of Punjab. Asian Journal of Chemistry, Ghaziabad, v. 14, n. 2, p. 746-752, 2002.

ARORA, S.; CHAHAL, D. S. Effect of soil properties on boron adsorption and release in arid and semi-arid Benchmark soils. Communications in Soil Science and Plant Analysis, New York, v. 41, n. 21, p. 2532-2544, 2010.

. Suitability of adsorption isotherms for behavior of

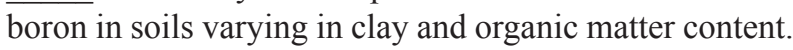
Agrochimica, Pacini, v. 51, n. 4-5, p. 182-193, 2007.

BARROW, N. J. Reactions with variable-charge soils. Dordrecht: Martinus Nijhoff Publishers, 1987. 191 p.

CHAUDHARY, D. R.; SHUKLA, L. M. Boron adsorption and desorption in arid soils of India. Agrochimica, Pacini, v. 48, n. 3-4, p. 141-152, 2004.

CHEN, W. T.; HO, S. B.; LEE, D. Y. Effect of $\mathrm{pH}$ on boron adsorption-desorption hysteresis of soils. Soil Science, Baltimore, v. 174, n. 6, p. 330-338, 2009.

COMMUNAR, G.; KEREN, R. Rate limited boron transport in soils: The effect of soil texture and solution pH. Soil Science Society of America Journal, Madison, v. 70, n. 3, p. 882-892, 2006.

EMPRESA BRASILEIRA DE PESQUISA AGROPECUÁRIA - EMBRAPA. Manual de métodos de análise de solo. 2. ed. Rio de Janeiro: Embrapa Solos, 1997. $212 \mathrm{p}$.

. Sistema brasileiro de classificação de solos. 2. ed. Rio de Janeiro: Embrapa Solos, 2006. 306 p.

GOLDBERG, S. Modeling boron adsorption isotherms and envelopes using the constant capacitance model. Soil Science Society of American Journal, Madison, v. 3, n. 2, p. 676-680, 2003.

. Reactions of boron with soils. Plant and Soil, Dordrechet, v. 193, n. 1-2, p. 35-48, 1997.

GOLDBERG, S.; CORWIN, D. L.; SUAREZ, D. L. Prediction of boron adsorption by field samples of diverse textures. Soil Science Society of America Journal, Madison, v. 69, n. 5, p. 1379-1388, 2005. 
GOLDBERG, S.; FORSTER, H. S.; HEICK, E. L. Boron adsorption mechanisms on oxides, clay minerals and soils inferred from ionic strength effects. Soil Science Society of America Journal, Madison, v. 57, n. 3, p. 704708, 1993.

GOLDBERG, S.; GLAUBIG, R. A. Boron adsorption on aluminum and iron oxide minerals. Soil Science Society of America Journal, Madison, v. 49, n. 6, p. 1374-1379, 1985.

GOLDBERG, S.; SUAREZ, D. L.; SHOUSE, P. J. Influence of soil solution salinity on boron adsorption by soils. Soil Science, Baltimore, v. 173, n. 6, p. 368-374, 2008 .

KEREN, R.; BINGHAM, F. T. Boron in water, soils, and plants. Advances in Soil Science. New York, v. 1, n. 4, p. 229-276, 1985.

ROSOLEM, C. A.; BÍSCARO, T. Adsorção e lixiviação de boro em Latossolo Vermelho-Amarelo. Pesquisa Agropecuária Brasileira, Brasília, v. 42, n. 10, p. 14731478, 2007.

SALTALI, K.; BILGILI, A. V.; TARAKCIOGLU, C.; DURAK, A. Boron adsorption in soils with different characteristics. Asian Journal of Chemistry, Ghaziabad, v. 17 , n. 4, p. 2487-2494, 2005.

SHAFIQ, M.; RANJHA, A. M.; YASEEN, M.; MEHDI, S. M.; HANNAN, A. Comparison of Freundlich and Langmuir adsorption equations for boron adsorption on calcareous soils. Journal of Agricultural Research, Washington, v. 46, n. 2, p. 141-148, 2008.
SHARMA, K. R.; SCRIVASTAVA, P. C.; SRIVASTVA, P.; SINGH, V. P. Effect of farmyard manure application on boron adsorption-desorption characteristics of some soils. Chemosphere, Oxford, v. 65, n. 5, p. 769-777, 2006.

SOARES, M. R.; ALLEONI, L. R. F.; CASAGRANDE, J. C. Parâmetros termodinâmicos da reação de adsorção de boro em solos tropicais altamente intemperizados. Química Nova, São Paulo, v. 28, n. 6, p. 1014-1022, 2005.

SOARES, M. R.; CASAGRANDE, J. C. Adsorção e modelos. In: RIBEIRO, M. R.; NASCIMENTO, C. W. A.; RIBEIRO FILHO, M. R.; CANTALICA, J. R. B. (Ed.). Tópicos em Ciência do Solo. Viçosa: Sociedade Brasileira de Ciência do Solo, p. 71-201, 2009.

SOARES, M. R.; CASAGRANDE, J. C.; ALLEONI, L. R. F. Adsorção de boro em solos ácricos em função da variação do pH. Revista Brasileira de Ciência do Solo, Viçosa, v. 32, n. 1, p. 111-120, 2008.

STEINER, F.; LANA, M. C.; ZOZ, T.; FEY, R.; FRANDOLOSO, J. F. Boron adsorption in lowland soils from Paraná State, Brazil. Semina: Ciências Agrárias, Londrina, v. 33, n. 4, p. 1391-1402, 2012.

YERMIYAHU, U.; KEREN, R.; CHEN, Y. Boron sorption by soil in the presence of composted organic matter. Soil Science Society of America Journal, Madison, v. 59, n. 2, p. 405-409, 1995. 
